\title{
ANALISIS BALANCED SCORECARD AGRIBISNIS JAMBU BIJI MERAH
}

\author{
${ }^{1)}$ Maimunah ${ }^{2)}$ Kristiawan \\ Dosen Fakultas Pertanian Universitas Sunan Bonang Tuban \\ Email : ${ }^{1)}$ mai.munah75@yahoo.co.id
}

\begin{abstract}
This study aims to see the extent to which red guava agribusiness performance in supporting business objectives, namely increasing income. The study was conducted on red guava farming in the District of Palang, Tuban Regency using the survey method. Sampling is done purposively, using balanced scorecard analysis to assess its performance. Data retrieval used to support analysis is data about income and sales (financial perspective), production costs and the number of products produced (customer perspective), how many sales innovations are carried out (internal business process perspective) and data on how many financial institutions are related in business development (learning perspective). The results of the study show that financial and customer perspectives have reached the achievement target, while the internal business process and learning perspective needs to be improved.
\end{abstract}

Keywords: Red Guava Agribusiness, performance, Balance scorecard

\section{PENDAHULUAN}

Peluang besar bagi pasar buah-buahan lokal Indonesia tidak hanya pada pasar ekspor saja, karena pasar lokal pun juga menyerap produk buah-buahan lokal dengan jumlah yang cukup besar. Hal ini dikarenakan masyarakat masih lebih memilih buahbuahan lokal yang lebih mudah didapatkan dan harganya relatif terjangkau masyarakat dari golongan menengah ke bawah maupun golongan yang mampu atau kaya. Kebutuhan buah-buahan juga terus meningkat bahkan menunjukkan kurangnya pasokan buahbuahan.

Hal tersebut dapat dilihat dari data dari BPS nasional adanya selisih negatif pada tingkat produksi dan kebutuhan. Dimana dengan rata-rata pertumbuhaan mencapai $1,12 \%$ pertahun, terjadi selisih kebutuhan dan produksi sebesar -145.554 di tahun 2013 dan 322.002 di tahun 2014. Tentu saja ini juga menunjukkan bahwa peluang pengembangan usahatani jambu biji merah yang merupakan buah lokal unggulan menjadi sebuah usahatani atau agribisnis yang lebih besar sangat terbuka. Salah satu produk hortikultura di Kabupaten Tuban yang telah dikembangkan dalam jumlah besar adalah Jambu Biji Merah.

Data statistik dari BPS Kabupaten Tuban menunjukkan bahwa jambu biji merah dibudidayakan di beberapa desa di wilayah kecamatan Palang, mengalami pertumbuhan. Pertumbuhan tampak dari kenaikan produksi dimana 111 ton di tahun 2016, naik menjadi 119 ton di tahun 2017. Menjadi usaha agribisnis yang mampu melihat peluang dan kesempatan merupakan harapan setiap petani.

Agribisnis yang demikian ini tentunya agribisnis yang memiliki visi misi yang jelas dan strategi yang mampu diterjemahkan dengan baik di lapang. Permasalahannya adalah apakah usahatani jambu bii merah ini telah memiliki pencapaian perspektif sesuai harapan. Sehingga tujuan penelitian ini adalah untuk melihat sejauh mana tingkat pencapaian usahatani dalam beberapa perspektif dalam Balanced Scorecard yang merupakan turunan dari tujuan usaha. 
Menurut (Sutawi, 2002) Agribisnis adalah suatu kegiatan bisnis atau usaha yang meliputi salah satu bahkan keseluruhan dari mata rantai produksi, pengolahan hasil, dan pemasaran yang berhubungan dengan pertanian dalam arti luas, yaitu kegiatan pertanian yang ditunjang oleh kegiatan usaha. Agribisnis yang memiliki daya saing yaitu agribisnis yang fleksibel dalam memberikan respon dinamika pasar serta mampu mencukupi kebutuhan pasar secara efektif dan efisien.

Pengembangan agroindustri meliputi berbagai macam wilayah salah satunya adalah pengembangan agroindustri pesisir (Hayati \& Nugroho, 2018). Jambu merah sebagai salah satu produk hortikultura yang perlu dikembangkan khususnya di Kabupaten Tuban.

BSC yaitu suatu mekanisme system manajemen yang dapat menerjemahkan visi maupun strategi organisasi kedalam tindakan nyata di lapangan. BSC dijadikan salah satu metode manajemen yang sudah terbukti dapat membantu banyak perusahaan dalam mengimplementasikan strategi bisnisnya. Keberhasilan penggunaan BSC sangat tinggi sehingga tidak hanya digunakan untuk system pengukuran kinerja tetapi juga dapat digunakan sebagai system manajemen strategis. Pada dasarnya BSC merupakan system yang mengukur kinerja dalam percobaan yang mengganti strategi maupun misi organisasi menjadi tujuan dan ukuran-ukuran yang lebih berwujud. Ukuran financial dan non finansial yang dirumuskan dalam perspektif BSC sebenarnya yaitu derivasi (penurunan) dari visi dan strategi organisasi. Maka dari itu hasil pengukuran menggunakan BSC ini dapat memberikan jawaban atas pertanyaan yang mengenai peningkat pencapaian organisasi dalam visi dan strategi yang telah ditetapkan (Nor, 2012). Di dalam Balanced Scorecard, ukuran financial memiliki dua fungsi penting, di mana yang utama yaitu seluruh perspektif bergantung pada pengukuran finansial yang ditunjukkan dengan implementasi dari strategi yang telah direncanakan dan yang kedua yaitu akan memberi dukungan kepada 3 perspektif yang lainnya mengenai target yang harus tercapai di dalam menggapai tujuan organisasi.

Kaplan dan Norton menyatakan bahwa siklus bisnis terbagi 3 tahap, yaitu: bertumbuh (growth), bertahan (sustain), dan menuai (harvest), dimana pada tahap-tahap tersebut memiliki tujuan finansial yang berbeda. Growth yaitu tahap pertama pada siklus suatu bisnis. Diharapkan pada tahap ini suatu usaha mempunyai produk baru yang sangat menguntungkan bagi usaha tersebut. Maka dari itu, di tahap growth dibutuhkan pertimbangan mengenai sumberdaya untuk perkembangan produk baru dan peningkatan layanan, pembangunan serta pengembangan fasilitas penunjang produksi, investasi pada sistem, infrastruktur dan jaringan distribusi yang mampu mendorong terjalinnya ikatan kerja secara keseluruhan dalam pengembangan ikatan yang baik dengan pelanggan. Tujuan finansial dari tahap ini secara keseluruhan yaitu pengukuran persentase tingkat pertumbuhan pemasukan dan tingkat pertumbuhan penjualan di pasar sasaran. Tahap selanjutnya yaitu sustain (bertahan), di mana pada tahap ini menimbulkan pertanyaan yang mencakup penarikan investasi atau melakukan investasi kembali dengan ditimbangkannya tingkat pengembalian yang mereka investasikan. Tujuan finansial yang ingin digapai dari tahap ini yaitu untuk mendapatkan keuntungan. Selanjutnya suatu bisnis akan mengalami suatu tahap yang dinamakan harvest (menuai), di mana suatu bisnis akan dipertahankan bisnisnya oleh organisasi atau badan usaha tersebut. Tujuan financial dari tahap ini yaitu untuk meningkatkan aliran kas dan mengurangi aliran dana. Menurut (Mulyadi, 2001), Balanced Scorecard mempunyai kelebihan yang menjadikan system manajemen strategi sekarang berbeda secara nyata dengan system manajemen strategi dalam system manajemen tradisional. Balanced Scorecard memperluas perspektif yang tercakup di dalam perencanaan strategi dari yang sebelumnya terbatas hanya pada perspektif keuangan, meluas menjadi tiga perspektif yang lain : costumer, proses bisnis internal, serta pertumbuhan dan pembelajaran. 


\section{METODE PENELITIAN}

Penelitian dilakukan pada usaha tani jambu biji merah yang terletak di Kecamatan Palang Kabupaten Tuban Jawa Timur. Pemilihan tempat ini dilakukan secara sengaja karena Kecamatan Palang merupakan sentra jambu biji merah dan merupakan wilayah pengembangan agropolitan baik Kabupaten Tuban maupun Jawa Timur.

Teknik pengumpulan data dalam penelitian ini adalah wawancara dan observasi.

Pengukuran pada penelitian ini yang digunakan analisis Balance scorecard dimana ada empat perspektif pengukuran yang dilakukan, yaitu :

Pertama, Perspektif Keuangan; pada perspektif ini digunakan pengukuran Profit Margin. Profit margin adalah rasio pendapatan terhadap penjualan. untuk melihat besar kecilnya laba usaha dalam hubungannya dengan penjualan dan untuk mengetahui efisiensi perusahaan.

Kedua, Perspektif Pelanggan. Pada perspektif ini pengukuran pengukuran yang digunakan yaitu profitabilitas pelanggan. Sebuah pendekatan manajemen biaya yang mengidentifikasi biaya dan manfaat melayani pelanggan individu atau kelompok pelanggan untuk meningkatkan profit perusahaan secara keseluruhan.

Ketiga, Perspektif Proses Bisnis Internal. Pada perspektif ini pengukuran yang digunakan adalah penilaian apakah dalam satu tahun terakhir ada pengembangan dalam hal produk baru/inovasi dari produk yang telah dimiliki dan sistem pemasaran yang digunakan.

Keempat.Perspektif Pertumbuhan dan Pembelajaran Sumber daya manusia, Apakah petani sudah menggunakan sumber daya yang ada dalam menyelesaikan masalah yang dihadapi baik dalam hal keuangan, pemeliharaan maupun pemasaran produk yang dihasilkan.

\section{HASIL DAN PEMBAHASAN}

Pertama, Perspektif Keuangan. Sasaran strategic pada perspektif keuangan adalah bagaimana mendapatkan keuntungan dan modal yang digunakan untuk memperluas usaha. Dari perhitungan didapat hasil bahwa profit margin yang diperoleh adalah sebesar $73,01 \%$, yang berarti nilainya lebih tinggi dari $8,3 \%$ atau target yang ditentukan. Nilai tersebut juga menunjukkan kemampuan laba yang didapatkan oleh petani adalah sebesar $73,01 \%$.Tercapainya profit margin usaha tani yang besar ini maka menunjukkan laba yang diperoleh usahatani ini juga tinggi.

Kedua, Profitabilitas pelanggan Analisis profitabilitas pelanggan yaitu suatu pendekatan manajemen biaya yang mengidentifikasi biaya serta manfaat melayani pelanggan individu maupun kelompok pelanggan dalam meningkatkan laba perusahaan secara menyeluruh.

Hasil pada perhitungan ini menunjukkan bahwa kontribusi laba yang diberikan oleh pelanggan dalam hal ini pembeli buah jambu rata-rata adalah sebesar 2.156,72/kg atau $26,96 \%$ dari harga penjualan.

Ketiga, Perspektif Proses Bisnis Internal. Sasaran strategic pada perspektif ini adalah peningkatan jumlah produk/jasa (pemasaran), Semakin besar nilai yang didapat maka semakin besar atau baik inovasi yang dilakukan.

Hasil penelitian menunjukkan bahwa ternyata petani tidak melakukan inovasi produk berupa pengolahan hasil produk untuk menambah jenis produk yang dijual. Demikian juga untuk bibit, meskipun petani telah dapat membuat bibit sendiri, tetapi dimanfaatkan untuk diri sendiri saja, belum dikembangkan lagi untuk menjadi produk lain yang dijual. Sedangkan pada pengukuran sasaran strategik inovasi pemasaran, didapat hasil pengukuran $33,3 \%$. 
Dari nilai inovasi yang lebih dari 0 menunjukkan bahwa petani telah mengusahakan adanya inovasi khususnya dari inovasi pemasaran. Dimana dalam satu tahun terakhir telah menggunakan model pemasaran baru yaitu melayani pembelian di kebun saat kunjungan ke kebun. Akan tetapi sebenarnya masih perlu ditingkatkan lagi, dengan memanfaatkan teknologi yang ada seperti media sosial.

Keempat, Perspektif proses pembelajaran dan pertumbuhan. Merupakan proses yang terpenting untuk membangun suatu organisasi. Apakah petani sudah menggunakan sumber daya yang ada dalam menyelesaikan masalah yang dihadapi baik dalam hal keuangan, pemeliharaan maupun pemasaran produk yang dihasilkan. Dalam hal ini keterlibatan lembaga keuangan dalam membantu menyelesaikan permasalahan modal yang dihadapi.

Hasil penelitian 50\% menunjukkan bahwa dalam hal keuangan petani telah memanfaatkan perbankan untuk membantu kesulitan permodalan yang dihadapi. Akan tetapi belum memanfaatkan koperasi yang ada dalam memenuhi kesulitan permodalan yang dihadapi. Hal ini dikarenakan seringkali rasa kepercayaan pada sebuah lembaga menjadi faktor penentu dalam menentukan lembaga mana yang akan digunakan.

Dalam hal keterlibatan karyawan, diperoleh hasil $16 \%$. Ini menunjukkan keterlibatan karyawan membantu penyelesaian permasalahan yang dihadapi petani telah dilakukan, khususnya pada saat memelihara maupun pemasaran. Hal ini sangat penting, karena petani adalah anggota masyarakat yang banyak terlibat dalam kegiatan. Petani juga adalah salah satu pegawai kelurahan yang memiliki kewajiban, sehingga jika seluruh keputusan hanya pada satu orang maka akan sulit dilakukan pekerjaan-pekerjaan khususnya yang bersifat teknis.

\section{Ukuran Pencapaian}

Setelah semua perspektif diukur maka berikut tabel yang menunjukkan keseluruhan sasaran strategik dari masing-masing perspektif yang dianalisa dan tingkat pencapaiannya.

\section{Tabel Target pencapaian dan Realisasi}

\begin{tabular}{|l|c|c|}
\hline \multicolumn{1}{|c|}{ Sasaran strategik } & Target & Realisasi \\
\hline $\begin{array}{l}\text { Perspektif keuangan } \\
\sim \text { Peningkatan profitabilitas }\end{array}$ & $8,30 \%$ & $73,01 \%$ \\
\hline $\begin{array}{l}\text { Perspektif Pelanggan } \\
\sim \text { Profitabilitas pelanggan }\end{array}$ & $8,30 \%$ & $26,96 \%$ \\
\hline $\begin{array}{l}\text { Perspektif Proses Bisnis Internal } \\
\sim \text { pengembangan produk }\end{array}$ & $100 \%$ & $33,30 \%$ \\
\hline $\begin{array}{l}\text { Perspektif Pertumbuhan dan Pembelajaran } \\
\sim \text { Keterlibatan karyawan } \\
\sim \text { Keterlibatan lembaga }\end{array}$ & $25 \%$ & $16 \%$ \\
& $100 \%$ & $50 \%$ \\
\hline
\end{tabular}

Dari tabel dapat kita lihat bahwa perpektif keuangan telah dapat mencapai target idealnya, demikian juga pada perspektif pelanggan. Ukuran pencapaian perpektif keuangan adalah ukuran yang menunjukkan kemudahan mendapatkan modal dan besarnya keuntungan yang diperoleh. Dalam penelitian ini pengukuran yang digunakan adalah pengukuran Profit Margin. Untuk melihat besar kecilnya laba usaha dalam hubungannya dengan penjualan dan untuk mengetahui efisiensi perusahaan maka 
digunakan pengukuran dengan profit margin. Jika rata-rata nilai profit margin sebesar 8,3\% maka nilai tersebut baik (Keown, 2008). Kemampuan perusahaan dalam mendapatkan laba yang cukup tinggi berpengaruh pada tingginya nilai profit margin, karena semakin tinggi nilai profit margin maka semakin baik. Harrison dan Horngern (1998) memaparkan bahwa margin laba kotor (gross profit margin) adalah pegukuran yang paling tepat dalam melihat profitabilitas. Besar kecilnya perubahan dalam rasio ini mampu memberikan indikasi pergerakan yang cukup besar dalam profitabilitas. Sehingga tingginya profit margin sangat diinginkan karena mampu memberi indikasi laba yang diperoleh melebihi harga pokok penjualan. Perspektif Pelanggan usaha tani jambu biji merah.

Pada perspektif ini, analisa profitabilitas pelanggan merupakan hal penting bagi usaha tani untuk mengetahui kontribusi keuntungan yang disumbangkan oleh setiap pelanggan serta untuk mengetahui kinerja masing-masing pelanggan yang dimilikinya. Analisis profitabilitas pelanggan dianggap sebagai praktik pemasaran yang baik dalam memelihara serta membangun ikatan yang menguntungkan dengan pelanggan. (Blocher, J, Edward, \& Stout, E, 2010) mendefinisikan customer profitability analysis sebagai berikut:

"Customer Profitability Analysis is an approach to cost management that identifies the costs and benefits of serving specific customers or customer types to improve an organization's overall profitability."

Analisa profitabilitas pelanggan bisa diartikan sebagai pendekatan manajemen biaya yang mengenalkan biaya serta manfaat melayani pelanggan individu atau kelompok pelanggan dalam meningkatkan laba perusahaan secara menyeluruh.

Hasil pada perhitungan ini menunjukkan bahwa kontribusi laba yang diberikan oleh pelanggan dalam hal ini pembeli buah jambu rata-rata adalah sebesar $2.156,72 / \mathrm{kg}$ atau 26,96\% dari harga penjualan. Dengan mengetahui besarnya kontribusi laba, maka petani dapat menetapkan berapa diskon yang dapat diberikan kepada pelanggan jika membeli dalam jumlah besar atau kontinyu.

Nilai realisasi perspektif keuangan yang melebihi target menunjukkan bahwa usaha ini prospektif untuk dikembangkan atau diadopsi oleh petani lain. Prospektif Pelanggan juga menunjukkan bahwa pelanggan telah memberikan kontribusi laba yang cukup besar dari harga jual yang dibayarkan oleh pembeli.

Pada perspektif Proses Bisnis Internal, tampak bahwa target yang ditetapkan masih belum dapat dicapai $100 \%$. Hal ini dimungkinkan karena usaha ini masih belum sepenuhnya memanfaatkan seluruh peluang atau belum membuat inovasi yang dapat meningkatkan keuntungan atau pendapatan perusahaan. Nilai pencapaian pada perspekttif ini juga mengindikasikan bahwa usaha masih belum sepenuhnya dikelola dengan baik. Dimungkinkan bahwa pengelolaan keuangan masih bercampur dengan pengelolaan keuangan pribadi sehingga pengambilam keputusan terkait dengan pemanfaatan peluang atau pengembangan inovasi belum sepenuhnya dilakukan. Selain itu pengelolaan yang juga masih bersifat sambilan, karena petani juga melakukan kegiatan lain sehingga perhatiannya masih terbagi dengan kegiatan lain tersebut. Dalam Perspektif Proses Bisnis Internal proses yang lebih diperhatikan adalah bagaimana proses internal usahatani ini dapat memberikan kepuasan kepada pelanggan, termasuk didalamnya adalah inovasi produk dan sistem pemasaran baru.

Pada perspektif Pertumbuhan dan Pembelajaran, keterbatasan modal memang merupakan kendala bagi pemilik usaha ini, tetapi sumber permodalan masih sepenuhnya digunakan. Petani memiliki kecenderungan menggunakan satu sumber lembaga saja yaitu perbankan. Lembaga lain seperti koperasi belum dimanfatkan untuk dapat membantu 
dalam pengembangan usahatani tersebut. Keterlibatan karyawan dalam menyelesaikan masalah juga perlu ditingkatkan.

\section{KESIMPULAN}

Hasil penelitian seperti yang diuraikan diatas, terhadap perspektif Balanced Scorecard menunjukkan bahwa Perspektif Keuangan, usaha yang dilakukan petani sangat baik dalam memperoleh keuntungan yang ditargetkan. Pada Perspektif pelanggan, kontribusi laba yang diberikan oleh pelanggan telah mencapai target yang ditetapkan. Perspektif Proses Bisnis Internal, menunjukkan belum tercapainya target untuk memuaskan pelanggan. Perspektif Proses Pembelajaran dan Pertumbuhan, keterlibatan karyawan telah berjalan dengan baik, akan tetapi keterlibatan lembaga keuangan dalam membantu permodalan masih belum sepenuhnya digunakan.

\section{DAFTAR PUSTAKA}

Blocher, J, Edward, \& Stout, E, D. (2010). Manajemen Biaya (5th ed.). Jakarta: Salemba Empat.

Hayati, N., \& Nugroho, T. R. D. A. (2018). Pengembangan Agroindustri Wilayah Pesisir Berbasis Komoditas Unggulan Ikan Hasil Tangkapan. Jurnal Sosial Ekonomi Dan Kebijakan Pertanian, 7(1). https://doi.org/http://dx.doi.org/10.21107/agriekonomika.v6i1.1895

Horngren, Charles T., W. T. H. J. (2007). Akuntansi (7th ed.). Jakarta: Erlangga.

Keown, A. J. (2008). Manajemen Keuangan (10th ed.). Jakarta: PT Macanan Jaya Cemerlang.

Mulyadi. (2001). Balanced Scorecard: Alat Manejemen Kontemporer untuk pelipatgandaan kinerja keuangan perusahaan. Jakarta: Salemba Empat.

Nor, W. (2012). Penerapan Balanced Scorecard Pada Pemerintah Daerah. Jurnal Akuntansi \& Bisnis, 7(2), 280-292.

Sutawi. (2002). Manajemen Agribisnis. Malang: UMM Press. 